Article

\title{
Assembling Polyiodides and Iodobismuthates Using a Template Effect of a Cyclic Diammonium Cation and Formation of a Low-Gap Hybrid Iodobismuthate with High Thermal Stability
}

\author{
Tatiana A. Shestimerova ${ }^{1}$, Andrei V. Mironov ${ }^{1}$, Mikhail A. Bykov ${ }^{1}$, Anastasia V. Grigorieva ${ }^{1,2} \mathbb{D}$, \\ Zheng Wei ${ }^{3}$, Evgeny V. Dikarev ${ }^{3}$ and Andrei V. Shevelkov ${ }^{1, *(1)}$ \\ 1 Department of Chemistry, Lomonosov Moscow State University, 119991 Moscow, Russia; \\ shestimerova@inorg.chem.msu.ru (T.A.S.); avmironov@inorg348-1.chem.msu.ru (A.V.M.); \\ mich.bykov@gmail.com (M.A.B.); anastasia.grigorieva@gmail.com (A.V.G.) \\ 2 Department of Materials Sciences, Lomonosov Moscow State University, 119991 Moscow, Russia \\ 3 Department of Chemistry, University at Albany, Albany, NY 12222, USA; zwei@albany.edu (Z.W.); \\ edikarev@albany.edu (E.V.D.) \\ * Correspondence: shev@inorg.chem.msu.ru; Tel.: +7-495-939-2074; Fax: +7-495-939-0998
}

Academic Editors: Maxim N. Sokolov and Sergey A. Adonin

Received: 28 May 2020; Accepted: 13 June 2020; Published: 15 June 2020

\begin{abstract}
Exploiting a template effect of 1,4-diazacycloheptane (also known as homopiperazine, Hpipe), four new hybrid iodides, $\left(\mathrm{HpipeH}_{2}\right)_{2} \mathrm{Bi}_{2} \mathrm{I}_{10} \cdot 2 \mathrm{H}_{2} \mathrm{O}$, $\left(\mathrm{HpipeH}_{2}\right) \mathrm{I}\left(\mathrm{I}_{3}\right),\left(\mathrm{HpipeH}_{2}\right)_{3} \mathrm{I}_{6} \cdot \mathrm{H}_{2} \mathrm{O}$, and $\left(\mathrm{Hpipe}_{2}\right)_{3}\left(\mathrm{H}_{3} \mathrm{O}\right) \mathrm{I}_{7}$, were prepared and their crystal structures were solved using single crystal X-ray diffraction data. All four solid-state crystal structures feature the $\mathrm{HpipeH}_{2}{ }^{2+}$ cation alternating with $\mathrm{Bi}_{2} \mathrm{I}_{10}{ }^{4-}, \mathrm{I}_{3}{ }^{-}$, or $\mathrm{I}^{-}$anions and solvent water or $\mathrm{H}_{3} \mathrm{O}^{+}$cation. $\mathrm{HpipeH}_{2}{ }^{2+}$ assembles anionic and neutral building blocks into polymer structures by forming four strong $(\mathrm{N}) \mathrm{H} \cdots \mathrm{I}$ and $(\mathrm{N}) \mathrm{H} \cdots \mathrm{O}$ hydrogen bonds per cation, with the $\mathrm{H} \cdots \mathrm{I}$ distances ranging from 2.44 to $2.93 \AA$ and $\mathrm{H} \cdots \mathrm{O}$ distances of $1.88-1.89$ $\AA$. These hydrogen bonds strongly affect the properties of compounds; in particular, in the case of $\left(\mathrm{HpipeH}_{2}\right)_{2} \mathrm{Bi}_{2} \mathrm{I}_{10} \cdot 2 \mathrm{H}_{2} \mathrm{O}$, they ensure narrowing of the band gap down to $1.8 \mathrm{eV}$ and provide high thermal stability up to $240{ }^{\circ} \mathrm{C}$, remarkable for a hydrated molecular solid.
\end{abstract}

Keywords: template effect; iodometallates; bismuth; polyiodides; crystal structure; intermolecular interactions; optical properties

\section{Introduction}

Bismuth is the heaviest chemical element to possess stable isotopes [1]. For decades, it has amused chemists by an astonishing variety of its molecular and condensed clusters that have no analogues among lighter elements [2-8]. Recently, other compounds of bismuth have become the objects of rapt attention. Today, halobismuthates are scrutinized as potential solar light absorbers to replace their efficient but toxic lead congeners. Although the photovoltaic efficiency of Bi-based solar cells has so far reached only $2.1 \%$, the search for new materials is gaining interest and new compounds have been recently synthesized and examined for potential photovoltaic properties [9-15]. In general, halobismuthates fulfill basic requirements for solar light harvesting. The $\mathrm{Bi}^{3+}$ cation possesses a polarizable electron shell prone to spin-orbit coupling, and its derivatives are stable against reduction and oxidation in addition to showing very low toxicity. However, in order to be good candidates, halobismuthates should also possess low band gaps; therefore, band gap engineering comes to the fore in creating Bi-based materials for solar light harvesting. 
Bismuth(III) forms quite a number of iodide complexes with various cations $[16,17]$. Inorganic compounds of a general formula $\mathrm{A}_{3} \mathrm{Bi}_{2} \mathrm{I}_{9}$, where $\mathrm{A}$ is a univalent cation, crystallize into two basic structure types. One of those features is a layered structure based on corner-shared $\left[\mathrm{BiI}_{6}\right]$ octahedra, whereas $\left[\mathrm{Bi}_{2} \mathrm{I}_{9}\right]^{3-}$ bioctahedra are the building blocks in another type. Both types were reported to have band gaps in the vicinity of $2 \mathrm{eV}$ as well as low photovoltaic efficiency. Other compounds with inorganic cations contain solvent water. Their band gaps are narrower, approaching $1.75 \mathrm{eV}$, and almost independent of the nature of the inorganic cation [18-20]. The major obstacle in the way of their application is low thermal stability; these compounds are known to decompose around 100 ${ }^{\circ} \mathrm{C}$. The band gap of iodobismuthates can be significantly reduced when bismuth iodide is combined with iodides of copper or silver. Several heterometallic iodides of this kind with different crystal structures have been prepared to date and their photovoltaic properties have been tested. It was shown that the gap width covers a wide range (1.5-2.5 eV), whereas the light-to-current efficiency depends on the structure and composition and varies from 0.83 to $3.17 \%$ [21-27]. Another route to low band gap iodobismuthates is introduction of $\mathrm{I}_{2}$ or $\mathrm{I}_{3}{ }^{-}$moieties into the crystal structures. In this way, several compounds with the band gap width around $1.5 \mathrm{eV}$ were recently synthesized [28-31]; however, their low thermal stability may severely limit potential applications.

Hybrid organic-inorganic iodobismuthates, as a rule, display moderate thermal stability, with decomposition temperatures near $200{ }^{\circ} \mathrm{C}$, even if a solvent is not incorporated into their structure. At the same time, the majority of these compounds have rather wide band gaps exceeding $2 \mathrm{eV}$, which makes them poor light harvesters. However, recent literature provides several examples of hybrid iodobismuthates with low band gaps, ranging from 1.59 to $1.80 \mathrm{eV}$ [32-36]. These compounds contain various organic cations and, more importantly, have different dimensionality of the anionic substructure, ranging from isolated anions to vertex-sharing $\mathrm{BiI}_{5}$ chains to edge-sharing $\mathrm{BiI}_{4}{ }^{-}$chains. The analysis of the crystal structures of hybrid iodobismuthates shows that features other than the dimensionality of the $\mathrm{Bi} / \mathrm{I}$ substructure play an important role in controlling the band gap width. Namely, they are multifold weak interactions that include hydrogen bonds (mainly $(\mathrm{N}) \mathrm{H} \cdots \mathrm{I})$ as well as interanionic I $\cdots I$ interactions [36-42]. DFT calculations reveal that weak non-covalent bonds are capable of promoting charge mobility along the direction of spreading such bonds in the crystal structure [34-39].

We propose that a strong organic base capable of forming hydrogen bonds with the $\left[\mathrm{BiI}_{6}\right]$ octahedra will favor the formation of a low band gap hybrid iodobismuthate irrespective of the dimensionality of the anionic $\mathrm{Bi} / \mathrm{I}$ substructure. In this work, we exploit the template effect of 1,4-diazacycloheptane (also known as homopiperazine, Hpipe) to synthesize a hybrid iodobismuthate $\left(\mathrm{HpipeH}_{2}\right)_{2} \mathrm{Bi}_{2} \mathrm{I}_{10} \cdot 2 \mathrm{H}_{2} \mathrm{O}$ with a band gap of $1.8 \mathrm{eV}$. We describe its crystal structure as well as of three other new compounds, $\left(\mathrm{HpipeH}_{2}\right)_{3} \mathrm{I}_{6} \cdot \mathrm{H}_{2} \mathrm{O}$, $\left(\mathrm{HpipeH}_{2}\right) \mathrm{I}\left(\mathrm{I}_{3}\right)$, and $\left(\mathrm{HpipeH}_{2}\right)_{3}\left(\mathrm{H}_{3} \mathrm{O}\right) \mathrm{I}_{7}$, that also manifest the same template mode of Hpipe. We were particularly concerned with the pattern of hydrogen bonds in all four compounds as well as the high thermal stability and promising optical properties of $\left(\mathrm{HpipeH}_{2}\right)_{2} \mathrm{Bi}_{2} \mathrm{I}_{10} \cdot 2 \mathrm{H}_{2} \mathrm{O}$.

\section{Results}

$\left(\mathrm{HpipeH}_{2}\right)_{2} \mathrm{Bi}_{2} \mathrm{I}_{10} \cdot 2 \mathrm{H}_{2} \mathrm{O}$ was synthesized in the form of a dark-red polycrystalline powder by a reaction between diluted hydroiodic acid solutions of 1,4-diazacycloheptane and $\mathrm{BiI}_{3}$. Upon washing with water and drying in air, the precipitate was analyzed for phase purity by means of powder X-ray diffraction, which showed a perfect match of the observed diffraction pattern with that calculated from the single crystal data (see Figure S1 of Supplementary Materials). The compound is stable for at least several weeks at ambient conditions. According to the thermal analysis (see Figure S2 of Supplementary Materials), its thermal decomposition starts upon heating to $240(2){ }^{\circ} \mathrm{C}$ releasing water, organic fragments, and then $\mathrm{BiI}_{3}$, which is known to be volatile above $300^{\circ} \mathrm{C}$.

In the absence of bismuth, Hpipe itself reacts with hydroiodic acid yielding different products depending on the concentration of the acid and on the presence of additional iodine in the solution. Yellowish-white $\left(\mathrm{Hpipe}_{2}\right)_{3} \mathrm{I}_{6} \cdot \mathrm{H}_{2} \mathrm{O}$ is readily obtained upon reacting Hpipe with $14 \%$ 
HI. With higher concentration of the acid (27\%), the reaction involves partial oxidation of HI by air oxygen, ultimately resulting in the formation of brown $\left(\mathrm{HpipeH}_{2}\right) \mathrm{I}\left(\mathrm{I}_{3}\right)$. When an excess of $14 \% \mathrm{HI}$ is used, $\left(\mathrm{HpipeH}_{2}\right)_{3} \mathrm{I}_{6} \cdot \mathrm{H}_{2} \mathrm{O}$ transforms into $\left(\mathrm{HpipeH}_{2}\right)_{3}\left(\mathrm{H}_{3} \mathrm{O}\right) \mathrm{I}_{7}$, which can be isolated as a yellow polycrystalline powder. Its reaction with $27 \% \mathrm{HI}$ involves partial oxidation of hydroiodic acid, yielding $\left(\mathrm{HpipeH}_{2}\right) \mathrm{I}\left(\mathrm{I}_{3}\right)$.

The crystal structure of each of the compounds described was determined from a single crystal. The summary of experimental and crystallographic information for studied compounds is given in Table 1. Selected interatomic distances are given in Table 2, with hydrogen bonding in Table 3.

Table 1. Structure Refinement Parameters.

\begin{tabular}{|c|c|c|c|c|}
\hline Parameters & $\left(\mathrm{HpipeH}_{2}\right)_{2} \mathrm{Bi}_{2} \mathrm{I}_{10} \cdot 2 \mathrm{H}_{2} \mathrm{O}$ & $\left(\mathrm{HpipeH}_{2}\right) \mathrm{I}\left(\mathrm{I}_{3}\right)$ & $\left(\mathrm{HpipeH}_{2}\right)_{3} \mathrm{I}_{6} \cdot \mathrm{H}_{2} \mathrm{O}$ & $\left(\mathrm{HpipeH}_{2}\right)_{3}\left(\mathrm{H}_{3} \mathrm{O}\right) \mathrm{I}_{7}$ \\
\hline Sum Formula & $\mathrm{C}_{5} \mathrm{H}_{16} \mathrm{BiI}_{5} \mathrm{~N}_{2} \mathrm{O}$ & $\mathrm{C}_{5} \mathrm{H}_{14} \mathrm{I}_{4} \mathrm{~N}_{2}$ & $\mathrm{C}_{15} \mathrm{H}_{44} \mathrm{I}_{6} \mathrm{~N}_{6} \mathrm{O}$ & $\mathrm{C}_{15} \mathrm{H}_{45} \mathrm{I}_{7} \mathrm{~N}_{6} \mathrm{O}$ \\
\hline Crystal system & triclinic & orthorhombic & orthorhombic & monoclinic \\
\hline Space Group & P-1 (№ 2) & Pbca (№ 61) & P2 ${ }_{1} 2_{1} 2_{1}$ (№ 19) & P2 1 /c (№ 14) \\
\hline$a, \AA$ & $8.3972(17)$ & $10.5196(3)$ & $10.3687(4)$ & $24.3883(14)$ \\
\hline$b, \AA$ & $10.4764(16)$ & $12.5020(4)$ & $12.1510(3)$ & $10.0774(6)$ \\
\hline$c, \AA$ & $11.0662(18)$ & $21.5362(5)$ & $25.3425(6)$ & $13.6539(8)$ \\
\hline$\alpha$, & $95.928(13)$ & 90 & 90 & 90 \\
\hline$\beta,{ }^{\circ}$ & $98.804(15)$ & 90 & 90 & $99.6360(10)$ \\
\hline$\gamma_{i}^{\circ}$ & $108.262(14)$ & 90 & 90 & 90 \\
\hline$V, \AA^{3}$ & $901.7(3)$ & $2832.36(14)$ & $3192.90(16)$ & $3308.4(3)$ \\
\hline Z & 2 & 8 & 4 & 4 \\
\hline$d_{\text {calc }}$ & 3.549 & 2.860 & 2.259 & 2.437 \\
\hline Radiation/wavelength & $\mathrm{AgK} \alpha / 0.56083$ & $\mathrm{CuK} \alpha / 1.54186$ & $\mathrm{CuK} \alpha / 1.54186$ & $\operatorname{MoK} \alpha / 0.71073$ \\
\hline Temperature, $\mathrm{K}$ & $295(2)$ & $293(2)$ & $293(2)$ & $100(2)$ \\
\hline Crystal form & block & block & plate & plate \\
\hline Crystal size, $\mathrm{mm}$ & $0.38 \times 0.26 \times 0.18$ & $0.25 \times 0.2 \times 0.15$ & $0.1 \times 0.05 \times 0.03$ & $0.16 \times 0.09 \times 0.02$ \\
\hline $\begin{array}{l}\text { Absorption } \\
\text { correction }\end{array}$ & psi-scan & multi-scan & multi-scan & multi-scan \\
\hline $\begin{array}{l}\theta \text { range (data } \\
\text { collection) }\end{array}$ & $2.03-24.96$ & $4.106-72.703$ & $3.49-72.93$ & $2.743-29.414$ \\
\hline Range of $h, k, l$ & $\begin{array}{c}-11 \rightarrow h \rightarrow 11 \\
-15 \rightarrow k \rightarrow 15 \\
0 \rightarrow l \rightarrow 16\end{array}$ & $\begin{array}{l}-12 \rightarrow h \rightarrow 13 \\
-7 \rightarrow k \rightarrow 12 ; \\
-25 \rightarrow l \rightarrow 26\end{array}$ & $\begin{array}{c}-12 \rightarrow h \rightarrow 12 \\
0 \rightarrow k \rightarrow 15 \\
0 \rightarrow l \rightarrow 31\end{array}$ & $\begin{array}{l}-33 \rightarrow h \rightarrow 33 \\
-13 \rightarrow k \rightarrow 13 \\
-18 \rightarrow l \rightarrow 18\end{array}$ \\
\hline$R_{\text {int }}$ & 0.0157 & 0.1176 & 0.1467 & 0.0459 \\
\hline$R / R_{w}$ & $0.0310 / 0.0607^{1}$ & $0.0399 / 0.1150^{1}$ & $0.0475 / 0.1203^{1}$ & $0.0299 / 0.0531^{2}$ \\
\hline GoF & 1.09 & 0.992 & 0.899 & 1.079 \\
\hline $\begin{array}{c}\text { No. of } \\
\text { params./reflections }\end{array}$ & $126 / 4987$ & $116 / 2806$ & $260 / 6313$ & $271 / 9143$ \\
\hline $\begin{array}{c}\Delta \rho_{\max }\left(\mathrm{e} / \AA^{-3}\right) \\
\text { positive/negative }\end{array}$ & $0.89 /-0.72$ & $0.93 /-1.48$ & $1.19 /-0.68$ & $1.132 /-1.477$ \\
\hline
\end{tabular}

Table 2. Selected Interatomic Distances and Angles in the Anionic Part of the Crystal Structures of $\left(\mathrm{Hpipe}_{2}\right)_{2} \mathrm{Bi}_{2} \mathrm{I}_{10} \cdot 2 \mathrm{H}_{2} \mathrm{O}$ and $\left(\mathrm{HpipeH}_{2}\right) \mathrm{I}\left(\mathrm{I}_{3}\right)$.

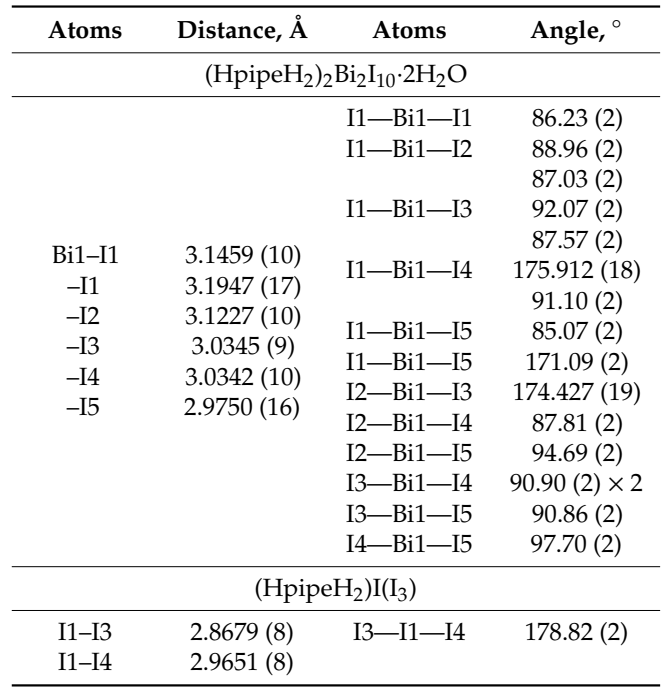


Table 3. Hydrogen Bonding in the Crystal Structures.

\begin{tabular}{|c|c|c|c|}
\hline D-H $\cdots A$ & $\mathrm{~d}(\mathrm{H} \cdots \mathrm{A}), \AA$ & $\mathrm{d}(\mathrm{D} \cdots \mathrm{A}), \AA$ & angle $(\mathrm{D}-\mathrm{H} \cdots \mathrm{A}){ }^{\circ}$ \\
\hline \multicolumn{4}{|c|}{$\left(\mathrm{HpipeH}_{2}\right)_{2} \mathrm{Bi}_{2} \mathrm{I}_{10}$} \\
\hline $\mathrm{N} 1-\mathrm{H} 12 \cdots \mathrm{I} 2$ & 2.79 & $3.543(8)$ & 139.5 \\
\hline 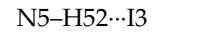 & 2.83 & $3.577(6)$ & 139.5 \\
\hline 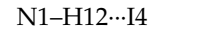 & 2.78 & $3.612(7)$ & 150.3 \\
\hline N5-H51O1 & 1.95 & $2.840(10)$ & 161.2 \\
\hline 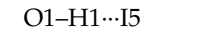 & $2.79(9)$ & $3.725(8)$ & $165(8)$ \\
\hline \multicolumn{4}{|c|}{$\left(\mathrm{HpipeH}_{2}\right) \mathrm{I}\left(\mathrm{I}_{3}\right)$} \\
\hline 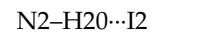 & $2.50(10)$ & $3.532(7)$ & $165(10)$ \\
\hline 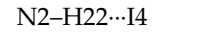 & $2.56(19)$ & $3.551(7)$ & $149(11)$ \\
\hline 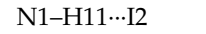 & $2.80(11)$ & $3.570(6)$ & $124(5)$ \\
\hline 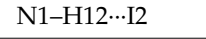 & $2.44(10)$ & $3.504(7)$ & $168(8)$ \\
\hline \multicolumn{4}{|c|}{$\left(\mathrm{HpipeH}_{2}\right)_{3} \mathrm{I}_{6} \cdot \mathrm{H}_{2} \mathrm{O}$} \\
\hline N1-H1A $\cdots$ I3 & 2.637 & $3.520(11)$ & 167.3 \\
\hline N1-H1B $\cdots I 1$ & 2.720 & $3.480(10)$ & 142.9 \\
\hline $\mathrm{N} 2-\mathrm{H} 2 \mathrm{~A} \cdots \mathrm{I} 2$ & 2.783 & $3.533(10)$ & 141.7 \\
\hline N2-H2B $\cdots$ I1 & 2.711 & $3.517(10)$ & 149.5 \\
\hline N3-H3A ‥ & 2.863 & $3.606(11)$ & 140.9 \\
\hline N3-H3B $\cdots \mathrm{O} 1$ & 1.880 & $2.772(14)$ & 170.8 \\
\hline N4-H4A ‥I1 & 2.832 & $3.577(10)$ & 141.0 \\
\hline N4-H4B $\cdots$ I2 & 2.733 & $3.510(10)$ & 145.1 \\
\hline N5-H5A ‥I4 & 2.739 & 3.547 (11) & 150.0 \\
\hline N5-H5B $\cdots$ I4 & 2.835 & $3.607(12)$ & 144.7 \\
\hline 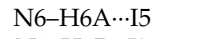 & 2.653 & $3.539(13)$ & 168.3 \\
\hline N6-H6B $\cdots$ I2 & 2.718 & $3.540(13)$ & 152.3 \\
\hline $\mathrm{O} 1-\mathrm{H} 1 \cdots \mathrm{I} 3$ & $2.65(9)$ & $3.515(10)$ & $144(12)$ \\
\hline $\mathrm{O} 1-\mathrm{H} 2 \cdots \mathrm{I} 5$ & $2.70(7)$ & $3.630(11)$ & $155(11)$ \\
\hline \multicolumn{4}{|c|}{$\left(\mathrm{HpipeH}_{2}\right)_{3}\left(\mathrm{H}_{3} \mathrm{O}\right) \mathrm{I}_{7}$} \\
\hline N0AA-H0AA $\cdots$ I7 & 2.689 & $3.508(3)$ & 150.2 \\
\hline N0AA-H0AB $\cdots$ I7 & 2.744 & $3.586(3)$ & 149.1 \\
\hline N5-H5A $\cdots$ I3 & 2.649 & $3.542(3)$ & 167.2 \\
\hline N5-H5B $\cdots$ I2 & 2.822 & $3.542(3)$ & 136.9 \\
\hline N2-H2C $\cdots \mathrm{I} 6$ & 2.706 & $3.515(3)$ & 148.7 \\
\hline N2-H2D $\cdots I 6$ & 2.718 & $3.539(3)$ & 150.5 \\
\hline N3-H3C $\cdots$ I5 & 2.656 & $3.545(3)$ & 165.9 \\
\hline N3-H3D ‥I2 & 2.831 & $3.521(3)$ & 133.6 \\
\hline N4-H4C $\cdots \mathrm{I} 1$ & 2.726 & $3.612(3)$ & 165.0 \\
\hline 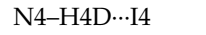 & 2.870 & $3.532(3)$ & 130.8 \\
\hline N6-H6C $\cdots$ I1 & 2.933 & $3.491(3)$ & 121.1 \\
\hline N6-H6D ‥I4 & 2.866 & $3.677(4)$ & 149.2 \\
\hline O1-H1D $\cdots \mathrm{I} 2$ & 2.609 & $3.467(4)$ & 170.8 \\
\hline O1-H1E $\cdots$ I3 & 2.796 & $3.605(4)$ & 156.7 \\
\hline
\end{tabular}

The crystal structure of $\left.(\mathrm{HpipeH})_{2}\right)_{2} \mathrm{Bi}_{2} \mathrm{I}_{10} \cdot 2 \mathrm{H}_{2} \mathrm{O}$ features three basic building blocks; they are the $\left[\mathrm{Bi}_{2} \mathrm{I}_{10}\right]^{4-}$ anion, the $\mathrm{HpipeH}_{2}{ }^{2+}$ cation, and water as an interstitial solvent (Figure 1). The $\mathrm{Bi}_{2} \mathrm{I}_{10}{ }^{4-}$ anion is an edge-shared bioctahedron; such a structural unit is frequently observed in various iodobismuthates [16,17]. The Bi-I distances to the bridging iodine atoms, 3.1459(10) and 3.1946(17) $\AA$, are slightly longer than the Bi-I bonds to terminal iodine atoms, 3.0344(9) and 3.1227(10) (Table 2). The anions are linked to the $\mathrm{HpipeH}_{2}{ }^{2+}$ cations via hydrogen $(\mathrm{N}) \mathrm{H} \cdots \mathrm{I}$ bonds (Table 3 ). The $(\mathrm{N}) \mathrm{H} \cdots \mathrm{I}$ interatomic distances of 2.72-2.77 $\AA$ are remarkably short compared to the hydrogen bond distances of $2.87 \AA$ and greater than that observed for similar contacts in various compounds [39,43], whereas the $(\mathrm{O}) \mathrm{H} \cdots \mathrm{I}$ distance of $2.79(9) \AA$ is usual for such kind of hydrogen bonds. The $\mathrm{N}-\mathrm{H} \cdots \mathrm{I}$ and $\mathrm{O}-\mathrm{H} \cdots \mathrm{I}$ angles substantially deviate from linearity, as typically encountered in similar assemblies $[43,44]$. In addition, there are numerous (C) $\mathrm{H} \cdots \mathrm{I}$ interatomic distances in the crystal structure, with the $\mathrm{H} \cdots \mathrm{I}$ separation ranging from 3.13 to $3.41 \AA$; the former distance may point at a very weak hydrogen bond, whereas the latter one is even greater than the sum of the respective van-der-Waals radii of $3.24 \AA$ [45]. Finally, the $\mathrm{I} \cdots \mathrm{I}$ separations between the iodine atoms of the neighboring $\left[\mathrm{Bi}_{2} \mathrm{I}_{10}\right]^{4-}$ anions exceed $4.14 \AA$. These are considerably longer than the I...I distances of 3.7-3.9 $\AA$, which were reported to have an impact on the electronic structure of iodobismuthates $[28,36,39]$ and are greater than the doubled van-der-Waals radii of iodine (4.08 $\AA$ [45]). 


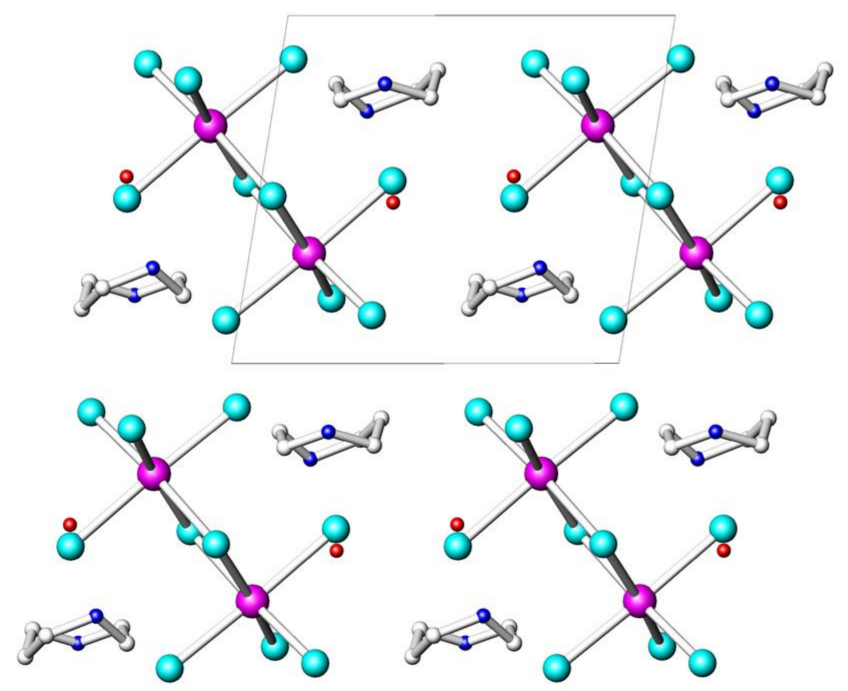

Figure 1. Projection of the crystal structure of $\left.(\mathrm{HpipeH})_{2}\right)_{2} \mathrm{Bi}_{2} \mathrm{I}_{10} \cdot 2 \mathrm{H}_{2} \mathrm{O}$ onto (100) plane. Bismuth, magenta; iodine, cyan; oxygen, red; nitrogen, blue; carbon, light gray. Hydrogen atoms are omitted for clarity. Unit cell is shown by thin black lines.

The Hpipe ${ }_{2}{ }^{2+}$ dication serves as a template to organize $\mathrm{Bi}_{2} \mathrm{I}_{10}{ }^{4-}$ anions and solvent water into a $3 \mathrm{D}$ crystal network. Each nitrogen atom of $\mathrm{HpipeH}_{2}{ }^{2+}$ has two hydrogen atoms and employs them to form hydrogen bonds with the anionic part. In the crystal structure of $\left(\mathrm{HpipeH}_{2}\right)_{2} \mathrm{Bi}_{2} \mathrm{I}_{10} \cdot 2 \mathrm{H}_{2} \mathrm{O}$, one nitrogen atom is involved in two (N)H...I bonds with iodine atoms of two different $\mathrm{Bi}_{2} \mathrm{I}_{10}{ }^{4-}$ anions, whereas another nitrogen atom forms one hydrogen bond of the same type and a $(\mathrm{N}) \mathrm{H} \cdots \mathrm{O}$ hydrogen bond of $1.88 \AA$ with solvent water, which is quite short compared to other organoammonium derivatives [40]. In this way, the $\mathrm{Hpipe}_{2}{ }^{2+}$ dication becomes surrounded by three $\mathrm{Bi}_{2} \mathrm{I}_{10}{ }^{4-}$ anions and one water molecule. The alternation of such hydrogen bonds throughout the crystal structure leads to the 3D pattern shown in Figure 2.

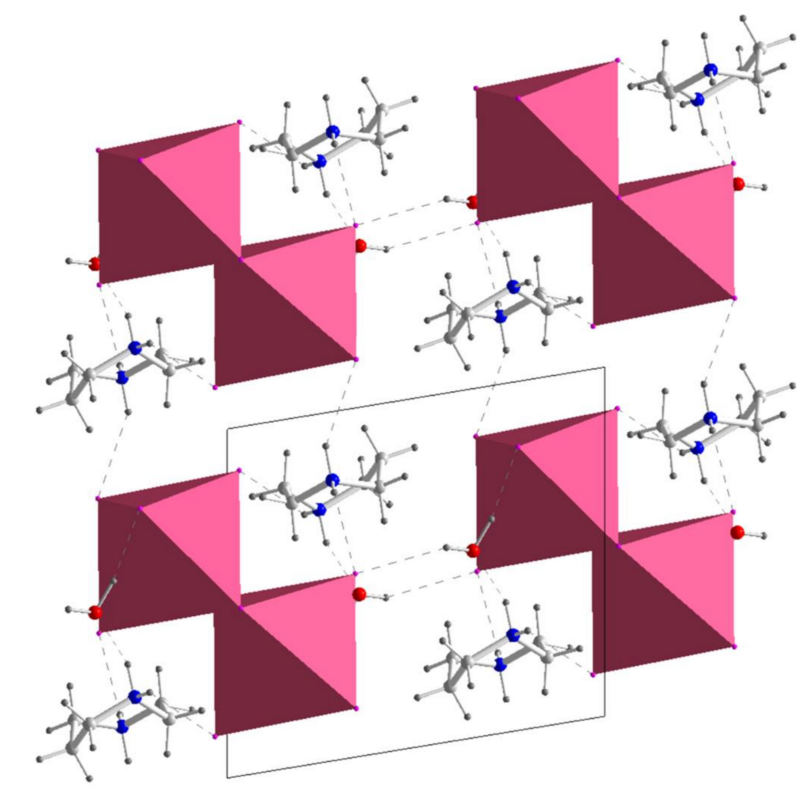

Figure 2. View of the crystal structure of $\left.(\mathrm{HpipeH})_{2}\right)_{2} \mathrm{Bi}_{2} \mathrm{I}_{10} \cdot 2 \mathrm{H}_{2} \mathrm{O}$ along the $c$ axis. $\mathrm{Bi}_{2} \mathrm{I}_{10}{ }^{4-}$ octahedra, magenta; oxygen, red; nitrogen, blue; carbon, light gray; hydrogen, dark gray. Hydrogen $(\mathrm{N}) \mathrm{H} \cdots \mathrm{O}$, $(\mathrm{O}) \mathrm{H} \cdots \mathrm{I}$, and $(\mathrm{N}) \mathrm{H} \cdots \mathrm{I}$ bonds are shown as dashed lines; the unit cell is depicted by thin black lines. 
The propensity of $\mathrm{HpipeH}_{2}{ }^{2+}$ to form four hydrogen bonds manifests itself in three other crystal structures that are revealed in this work (Figure 3). In homopiperazinium iodide-triiodide, $\left(\mathrm{HpipeH}_{2}\right) \mathrm{I}\left(\mathrm{I}_{3}\right)$, the $\mathrm{HpipeH}_{2}{ }^{2+}$ cation forms four $(\mathrm{N}) \mathrm{H} \cdots \mathrm{I}$ bonds, of which three connect the dication with monoatomic $\mathrm{I}^{-}$anions, whereas the forth bond links the dication with the triiodide anion $\mathrm{I}_{3}{ }^{-}$ through the terminal iodine atom (Figure 4 ). The crystal structure of homopiperazinium iodide monohydrate, $\left(\mathrm{HpipeH}_{2}\right)_{3} \mathrm{I}_{6} \cdot \mathrm{H}_{2} \mathrm{O}$, is a bit more complex. It shows two modes of the $\mathrm{HpipeH}_{2}{ }^{2+}$ cation involvement in hydrogen bonding. The first one is essentially the same as in $\left(\mathrm{HpipeH}_{2}\right)_{2} \mathrm{Bi}_{2} \mathrm{I}_{10} \cdot 2 \mathrm{H}_{2} \mathrm{O}$, where three iodine atoms and one water molecule assemble around $\mathrm{HpipeH}_{2}{ }^{2+}$. The second mode is coordination of four $\mathrm{I}^{-}$anions by $(\mathrm{N}) \mathrm{H} \cdots \mathrm{I}$ bonds. Finally, the $\mathrm{HpipeH}_{2}{ }^{2+}$ cation forms four $(\mathrm{N}) \mathrm{H} \cdots \mathrm{I}$ bonds in the crystal structure of $\left(\mathrm{HpipeH}_{2}\right)_{3}\left(\mathrm{H}_{3} \mathrm{O}\right) \mathrm{I}_{7}$; however, the latter crystal structure features a more complex array of hydrogen bonds as it involves the $\mathrm{H}_{3} \mathrm{O}^{+}$oxonium cation that forms $(\mathrm{O}) \mathrm{H} \cdots \mathrm{I}$ bonds with three $\mathrm{I}^{-}$anions, leading to the $1 \mathrm{D}$ pattern of hydrogen bonds shown in Figure 5. $\mathrm{The}_{3} \mathrm{H}^{+}$ cation is involved only in $(\mathrm{O}) \mathrm{H} \cdots \mathrm{I}$ bonds, which makes its role different from that in the crystal structure of $\left(\mathrm{H}_{3} \mathrm{O}\right) \mathrm{Rb}_{3} \mathrm{BiI}_{7} \cdot 4 \mathrm{H}_{2} \mathrm{O}$. In the latter, the $\mathrm{H}_{3} \mathrm{O}^{+}$cation, along with water molecules, forms a $1 \mathrm{D}\left(\mathrm{H}_{11} \mathrm{O}_{5}\right)^{+}$ polymeric cation, which takes part in interactions with $\mathrm{Rb}^{+}$cations [46].
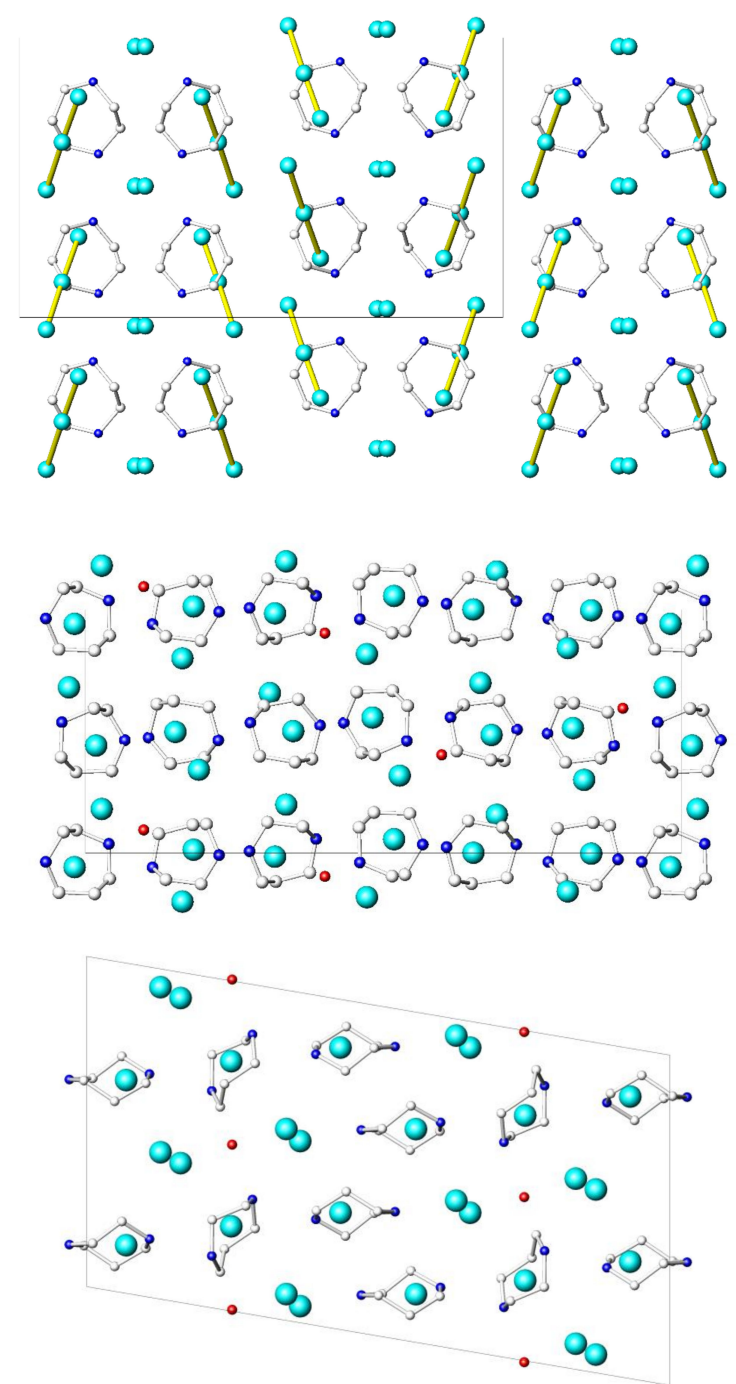

Figure 3. Projections of the crystal structures of $\left(\mathrm{HpipeH}_{2}\right) \mathrm{I}\left(\mathrm{I}_{3}\right)$ on the [010] plane (top), $\left(\mathrm{Hpipe}_{2}\right)_{3} \mathrm{I}_{6} \cdot \mathrm{H}_{2} \mathrm{O}$ on the [100] plane (middle), and $\left(\mathrm{HpipeH}_{2}\right)_{3}\left(\mathrm{H}_{3} \mathrm{O}\right) \mathrm{I}_{7}$ on the [010] plane (bottom). Iodine, cyan; oxygen, red; nitrogen, blue; carbon, light gray. Hydrogen atoms are omitted for clarity. Black lines show unit cells. 


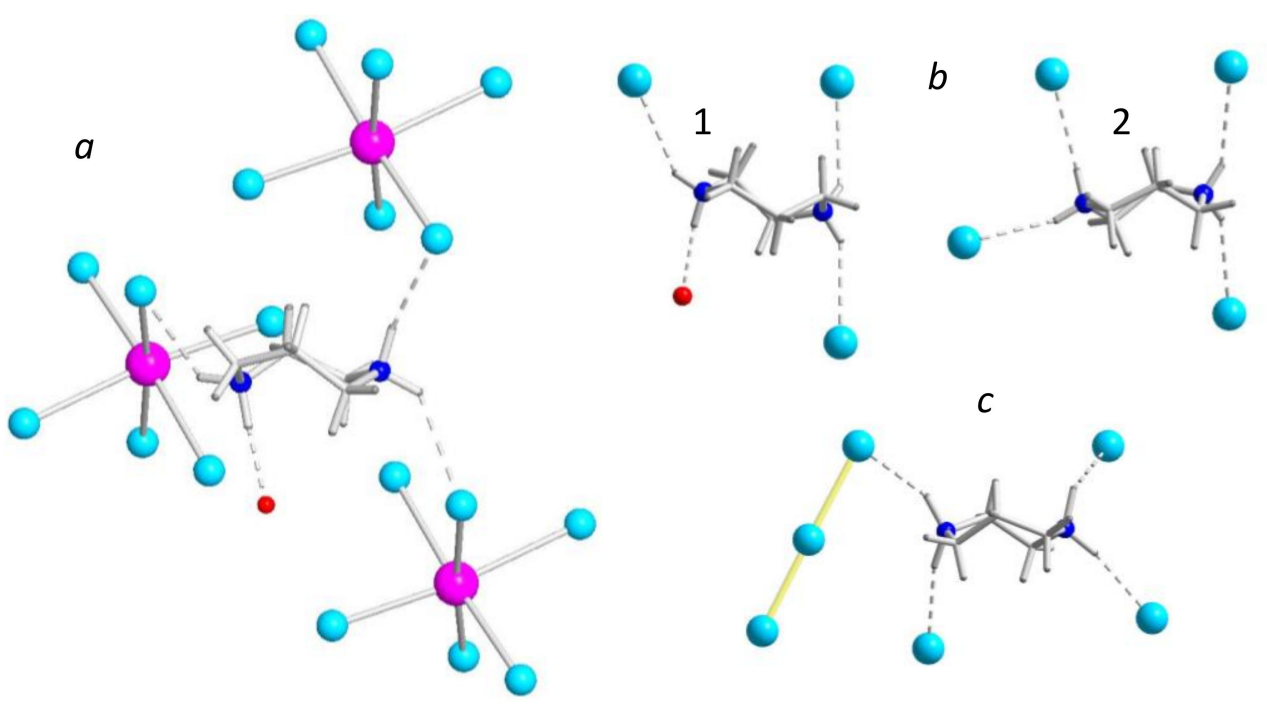

Figure 4. The surroundings of $\mathrm{HpipeH}_{2}{ }^{2+}$ cations in the crystal structures of $\left(\mathrm{HpipeH}_{2}\right)_{2} \mathrm{Bi}_{2} \mathrm{I}_{10} \cdot 2 \mathrm{H}_{2} \mathrm{O}(\mathbf{a})$, $\left(\mathrm{Hpipe}_{2}\right)_{3} \mathrm{I}_{6} \cdot \mathrm{H}_{2} \mathrm{O}(\mathbf{b})$, and $\left(\mathrm{HpipeH}_{2}\right) \mathrm{I}\left(\mathrm{I}_{3}\right)$ (c). Bismuth, magenta; iodine, cyan; oxygen, red; nitrogen, blue; carbon, light gray, hydrogen, dark gray. Hydrogen $(\mathrm{N}) \mathrm{H} \cdots \mathrm{O}$ and $(\mathrm{N}) \mathrm{H} \cdots \mathrm{I}$ bonds are shown as dashed lines. Note that the surrounding of $\mathrm{HpipeH}_{2}{ }^{2+}$ cations in the crystal structure of $\left(\mathrm{HpipeH}_{2}\right)_{3}\left(\mathrm{H}_{3} \mathrm{O}\right) \mathrm{I}_{7}$ is the same as in $\left(\mathrm{HpipeH}_{2}\right)_{3} \mathrm{I}_{6} \cdot \mathrm{H}_{2} \mathrm{O}$, type $2(\mathrm{~b})$.

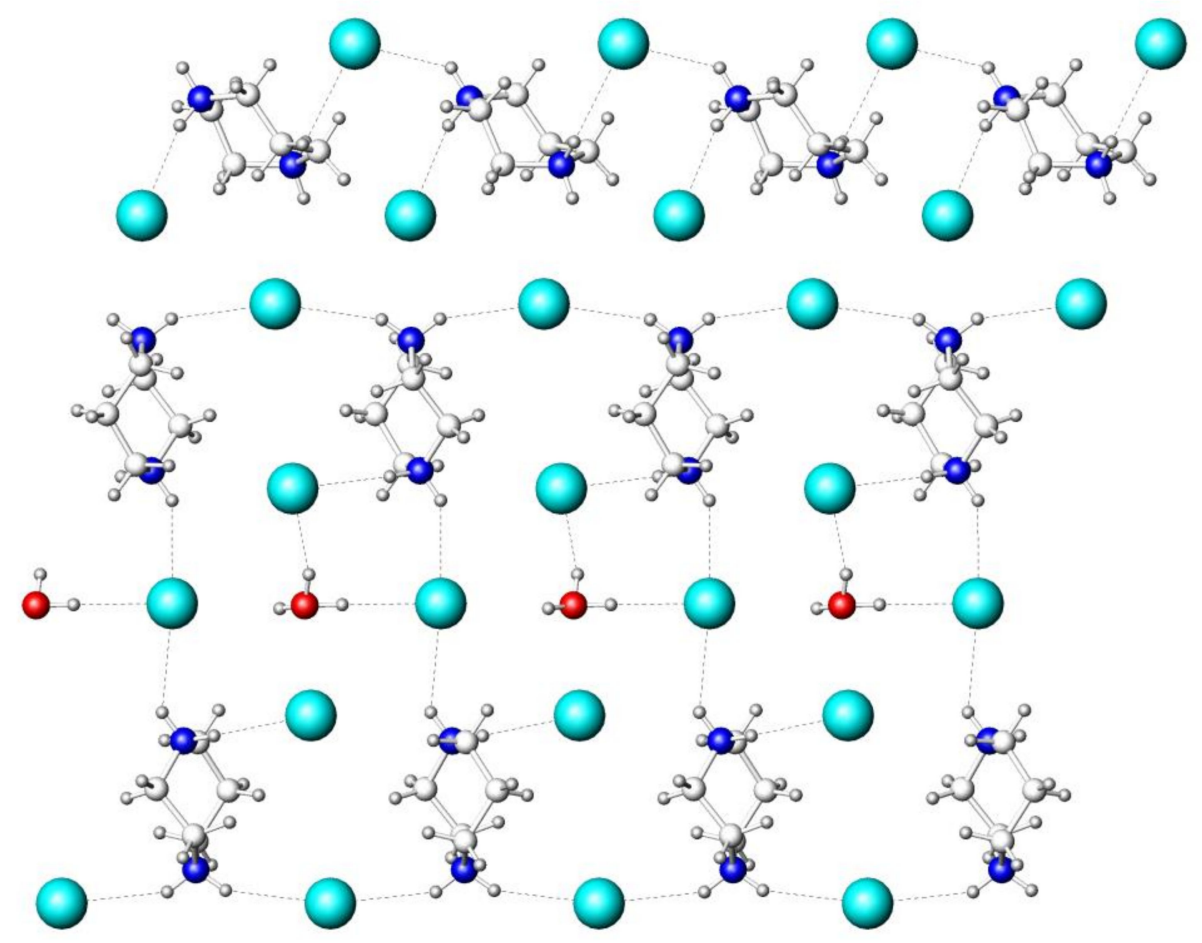

Figure 5. Pattern of hydrogen bonds in the crystal structure of $\left(\mathrm{HpipeH}_{2}\right)_{3}\left(\mathrm{H}_{3} \mathrm{O}\right) \mathrm{I}_{7}$ involving $\mathrm{HpipeH}_{2}{ }^{2+}$ and $\mathrm{H}_{3} \mathrm{O}^{+}$cations and iodide anions. Two strands running along the $c$ axis are shown. Iodine, cyan; oxygen, red; nitrogen, blue; carbon, light gray, hydrogen, dark gray. Hydrogen $(\mathrm{N}) \mathrm{H} \cdots \mathrm{O}$ and $(\mathrm{N}) \mathrm{H} \cdots \mathrm{I}$ bonds are shown as dashed lines.

The length of the $(\mathrm{N}) \mathrm{H} \cdots \mathrm{I}$ bonds in $\left(\mathrm{HpipeH}_{2}\right) \mathrm{I}\left(\mathrm{I}_{3}\right),\left(\mathrm{HpipeH}_{2}\right)_{3} \mathrm{I}_{6} \cdot \mathrm{H}_{2} \mathrm{O}$, and $\left(\mathrm{HpipeH}_{2}\right)_{3}\left(\mathrm{H}_{3} \mathrm{O}\right) \mathrm{I}_{7}$ covers the range of 2.44-2.93 $\AA$, which is considerably wider than the range of the respective distances found in $\left(\mathrm{HpipeH}_{2}\right)_{2} \mathrm{Bi}_{2} \mathrm{I}_{10} \cdot 2 \mathrm{H}_{2} \mathrm{O}(2.72-2.77 \AA)$. The distance of 2.44(10) $\AA$ is remarkably short for the $(\mathrm{N}) \mathrm{H} \cdots \mathrm{I}$ bond. Strong hydrogen bonds influence the geometry of the $\mathrm{I}_{3}{ }^{-}$anion in the crystal structure of $\left(\mathrm{HpipeH}_{2}\right) \mathrm{I}\left(\mathrm{I}_{3}\right)$. This anion is asymmetric; the I-I distances are $2.8679(8)$ and 2.9651(8) $\AA$ and the 
I-I-I angle is $178.82(2)$ deg. Such asymmetry stems from the binding mode of the $\mathrm{I}_{3}{ }^{-}$anion, where only

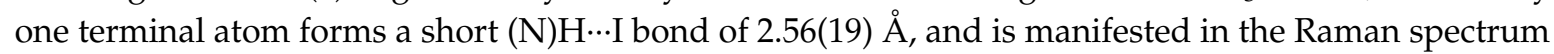
(Figure 6), which features two bands that can be assigned to symmetric and asymmetric stretching modes [47]. The former is observed at $115 \mathrm{~cm}^{-1}$ and is supplemented by scarcely visible overtone satellites at about 230 and $340 \mathrm{~cm}^{-1}$. It has a slightly higher Raman shift than normally observed for the triiodide anion $\left(110 \mathrm{~cm}^{-1}\right),[48,49]$ but that can be explained by a slightly shorter average I-I interatomic distance $(2.92 \AA)$ compared to what is typical for the $\mathrm{I}_{3}{ }^{-}$anion $(2.94 \AA)$ [50]. The band at $132 \mathrm{~cm}^{-1}$ should be attributed to the asymmetric stretch mode, which is typically observed in the range of $130-140 \mathrm{~cm}^{-1}$. For the $\mathrm{I}_{3}^{-}$anion adopting $D_{\infty h}$ symmetry, this vibration is Raman-inactive; however, the intensity of this band grows with the degree of the $\mathrm{I}_{3}{ }^{-}$anion deviation from the $D_{\infty h}$ symmetry.

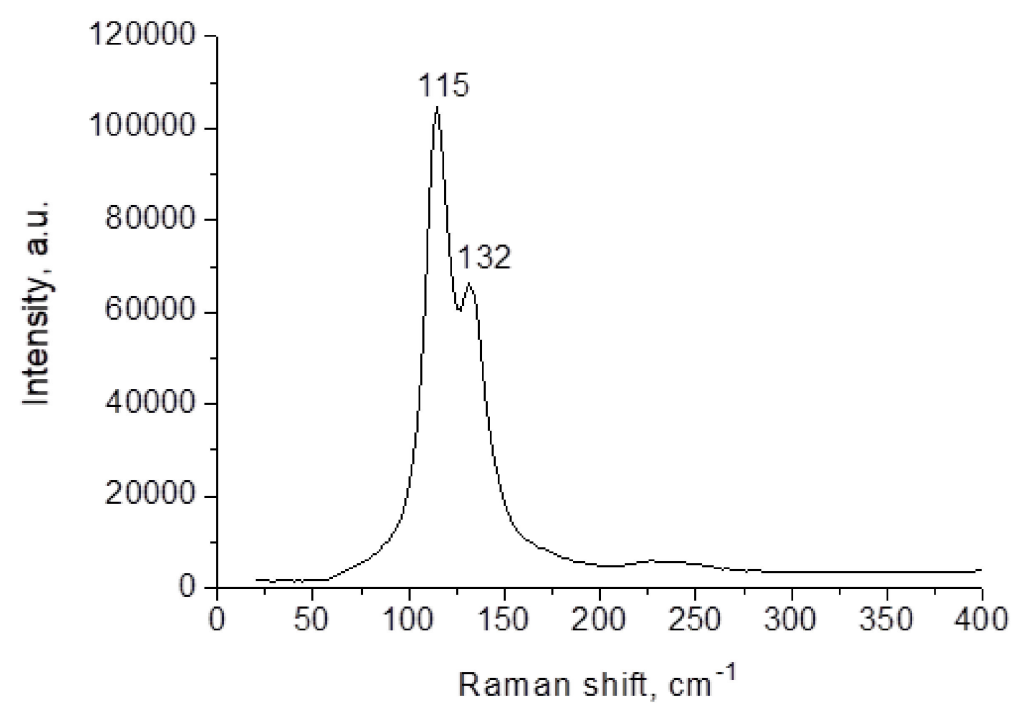

Figure 6. Raman spectrum of $\left(\mathrm{HpipeH}_{2}\right) \mathrm{I}\left(\mathrm{I}_{3}\right)$.

We would like to emphasize that most of the hydrogen bonds in the four title crystal structures are quite short. The lengths apparently reflect the strength of such bonds, most likely associated with the base strength of Hpipe. A considerable number of strong hydrogen bonds ensures assembling of the molecular units into patterns infinite in one, $\left(\mathrm{HpipeH}_{2}\right)_{3}\left(\mathrm{H}_{3} \mathrm{O}\right) \mathrm{I}_{7}$, two, $\left(\mathrm{HpipeH}_{2}\right)_{3} \mathrm{I}_{6} \cdot \mathrm{H}_{2} \mathrm{O}$ and $\left(\mathrm{HpipeH}_{2}\right) \mathrm{I}\left(\mathrm{I}_{3}\right)$, or three, $\left(\mathrm{HpipeH}_{2}\right)_{2} \mathrm{Bi}_{2} \mathrm{I}_{10} \cdot 2 \mathrm{H}_{2} \mathrm{O}$, directions. The latter compound exhibits rather high thermal stability up to $240{ }^{\circ} \mathrm{C}$, quite remarkable for a hydrated molecular solid. One can argue that the main reason for such stability is a $3 \mathrm{D}$ pattern of rather strong hydrogen bonds (Figure 2).

Optical diffuse reflectance measured for a polycrystalline powder of $\left(\mathrm{HpipeH}_{2}\right)_{2} \mathrm{Bi}_{2} \mathrm{I}_{10} \cdot 2 \mathrm{H}_{2} \mathrm{O}$ and converted into absorbance data is plotted versus energy in Figure 7. Extrapolation of the linear part of the Kubelka-Munk plot onto the energy axis gives the value of a direct band gap of $1.8 \mathrm{eV}$, which is in line with the dark-red color of the compound. It was previously shown that the charge transfer in iodobismuthates proceeds from iodine $5 p$ orbitals lying at the top of the valence band to bismuth $6 p$ orbitals forming the bottom of the conduction band [19]. However, the structure of the top of the valence band and the bottom of the conduction band may be affected by additional contributions. Two of those, namely, I -.I secondary interactions and polyiodide moieties can be ruled out as absent in the crystal structure of $\left(\mathrm{HpipeH}_{2}\right)_{2} \mathrm{Bi}_{2} \mathrm{I}_{10} \cdot 2 \mathrm{H}_{2} \mathrm{O}$. The remaining factor influencing the band gap width is the interaction between the cation and anion. Unlike the case of $\left(\mathrm{C}_{7} \mathrm{H}_{7}\right) \mathrm{BiI}_{4}$, in which the cation-to-anion charge transfer takes place [51], the shrinkage of the band gap in the title compound can be attributed to the contribution of hydrogen bonds. Firstly, strong (N)H $\cdots$ I hydrogen bonds slightly push iodine $5 p$ orbitals to higher energy rendering smaller width of the ban gap; secondly, hydrogen bonds are capable of promoting mobility of charge carriers, ensuring 3D conductivity in solids composed of OD Bi/I anions [34,39,52,53]. The stronger the non-covalent (hydrogen) bond is, 
the higher the mobility should be. In $\left(\mathrm{HpipeH}_{2}\right)_{2} \mathrm{Bi}_{2} \mathrm{I}_{10} \cdot 2 \mathrm{H}_{2} \mathrm{O}$, very strong hydrogen bonds provoke reduction of the band gap from 2.0-2.2 eV, typical for compounds built of $0 \mathrm{D} \mathrm{Bi/I} \mathrm{anions} \mathrm{[53,54],} \mathrm{to} \mathrm{as}$ low as $1.8 \mathrm{eV}$. The latter ensures efficient absorption of the solar light, which is favorable for the creation of light-harvesting materials for new solar cells.

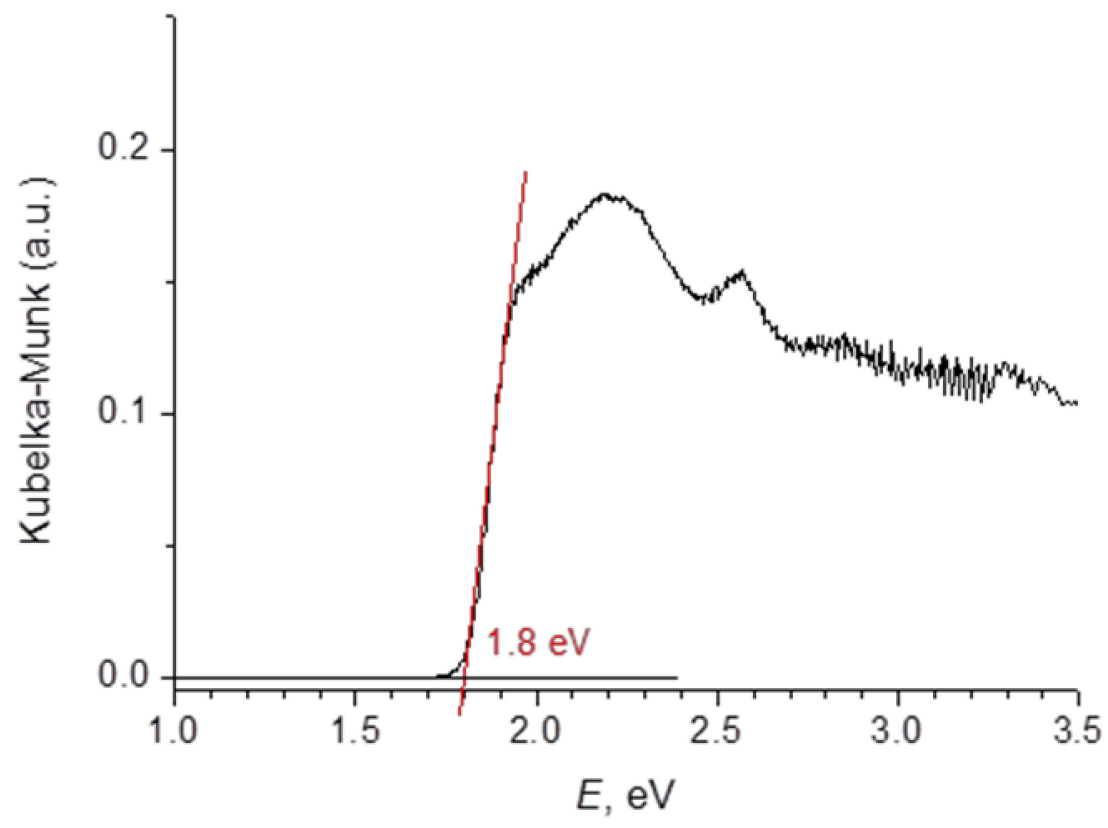

Figure 7. Kubelka-Munk plot for $\left(\mathrm{HpipeH}_{2}\right)_{2} \mathrm{Bi}_{2} \mathrm{I}_{10} \cdot 2 \mathrm{H}_{2} \mathrm{O}$.

\section{Materials and Methods}

\subsection{Synthesis}

Used as starting materials were Bi (granules, 99.99\%), $\mathrm{I}_{2}$ (analytical grade), 1,4-diazacycloheptane (analytical grade), $\mathrm{P}$ (pure), and $\mathrm{H}_{2} \mathrm{O}$ (distilled). $\mathrm{BiI}_{3}$ was synthesized from the elements, and hydroiodic acid (stabilized) was synthesized by hydrolysis of freshly prepared $\mathrm{PI}_{3}$; details of these procedures are described elsewhere [19]. The HI acid (stabilized) was distilled at $126^{\circ} \mathrm{C}$, and the resulting solution was diluted with distilled water to required concentrations.

For the preparation of $\left(\mathrm{HpipeH_{2 }}\right)_{2} \mathrm{Bi}_{2} \mathrm{I}_{10} \cdot 2 \mathrm{H}_{2} \mathrm{O}, 10 \mathrm{ml}$ of aqueous solution containing $10 \mathrm{wt}$ \% of $\mathrm{HI}$ was added to the starting reagents taken in a molar ratio of $\mathrm{BiI}_{3}: H$ pipe $=1: 1$ with a total weight of $0.2 \mathrm{~g}$. The flask with the resulting solution was left for evaporation in open air for five days to yield dark-red well-shaped crystals. These crystals were separated by filtration and dried at room temperature. A mixture of large yellow crystals of $\left(\mathrm{HpipeH}_{2}\right)_{3} \mathrm{I}_{6} \cdot \mathrm{H}_{2} \mathrm{O}$ and large column-shaped brown crystals of $\left(\mathrm{Hpipe}_{2}\right) \mathrm{I}\left(\mathrm{I}_{3}\right)$ was obtained by slow evaporation of a homopiperazine solution in a $27 \mathrm{wt}$. \% of HI. Pure compounds of these compositions were obtained by the following procedures: For the preparation of $\left(\mathrm{HpipeH}_{2}\right)_{3} \mathrm{I}_{6} \cdot \mathrm{H}_{2} \mathrm{O}, 4 \mathrm{ml}$ of aqueous solution containing $14 \mathrm{wt}$ \% of $\mathrm{HI}$ was added to $0.5 \mathrm{~g}$ of Hpipe. Yellowish crystals formed immediately. For the preparation of $\left(\mathrm{HpipeH}_{2}\right) \mathrm{I}\left(\mathrm{I}_{3}\right), 10 \mathrm{ml}$ of the aqueous solution containing $50 \mathrm{wt}$ \% of $\mathrm{HI}$ were added to a mixture of $1 \mathrm{~g}$ of Hpipe and $0.5 \mathrm{~g} \mathrm{I}_{2}$ and the resulting solution was kept in air until complete evaporation of the solvent, which yields brown crystals of the target compound. $\left(\mathrm{HpipeH}_{2}\right)_{3}\left(\mathrm{H}_{3} \mathrm{O}\right) \mathrm{I}_{7}$ was obtained by adding a 10-fold excess of $\mathrm{HI}$ (14 wt.\%) to the aqueous solution of Hpipe. The resulting solution was evaporated almost to dryness to yield yellowish-white $\left(\mathrm{HpipeH}_{2}\right)_{3}\left(\mathrm{H}_{3} \mathrm{O}\right) \mathrm{I}_{7}$ contaminated by a minor impurity of $\left(\mathrm{HpipeH}_{2}\right)_{3} \mathrm{I}_{6} \cdot \mathrm{H}_{2} \mathrm{O}$. 


\subsection{Powder X-Ray Diffraction Analysis (PXRD)}

Powder X-Ray diffraction analysis (PXRD) was performed on an Imaging Plate Guinier Camera (Huber G670, Cu-K $\mathrm{K}_{\alpha 1}$ radiation, $\lambda=1.540598 \AA$ А, Huber Diffraktionstechnik GmbH \& Co. KG, Rimsting, Germany) with the $2 \theta$ ranging from 5 to $77 \mathrm{deg}$. For the analysis, crystals were finely crushed in an agate mortar, and the resulting powder was fixed on a holder using scotch tape.

\subsection{Crystal Structure Determination}

Single crystals of $\left.(\mathrm{HpipeH})_{2}\right)_{2} \mathrm{Bi}_{2} \mathrm{I}_{10} \cdot 2 \mathrm{H}_{2} \mathrm{O}$ were selected directly from the synthetic mixture. Single crystal diffraction data were measured on a CAD4 diffractometer equipped with an $\mathrm{Ag} \mathrm{K \alpha}$ $\mathrm{X}$-ray tube. The experimental data were corrected for Lorenz and polarization factors and absorption effect. The structure was solved by direct methods (SIR2002 program package) [55]. The solution of the crystal structure revealed bismuth and iodine atoms arranged in pairs of edge-sharing $\left[\mathrm{BiI}_{6}\right]$ octahedra. Structure refinement and successive Fourier synthesis (JANA 2000 [56]) revealed $\mathrm{C}_{5} \mathrm{~N}_{2}$ rings and additional separate atoms, which were interpreted as water oxygens. Hydrogen atoms near carbons were placed geometrically and refined constrained in a riding mode. Difference Fourier synthesis in the vicinity of nitrogen atoms showed several residual peaks at distances corresponding to hydrogen atoms. Being refined independently they appeared in reasonable (but not perfect) positions with good atomic displacement parameters. For the final refinement, they were placed geometrically and refined constrained. The additional proof of such an approach is the charge neutrality of the structure. At the final stage, the oxygen atom was replaced by the water molecule, which was refined as a rigid body with fixed interatomic distances and angles.

Well-shaped single crystals of $\left(\mathrm{HpipeH}_{2}\right)_{3} \mathrm{I}_{6} \cdot \mathrm{H}_{2} \mathrm{O}$ and $\left(\mathrm{HpipeH}_{2}\right) \mathrm{I}\left(\mathrm{I}_{3}\right)$ were selected from the respective synthetic mixtures. The $X$-ray intensity data were measured at $293 \mathrm{~K}$ on a STOE StadiVari Pilatus $100 \mathrm{~K}$ diffractometer system equipped with a Cu-target $X$-ray tube $(\lambda=0.56083 \AA)$ and a graphite monochromator (Stoe \& Cie GmbH, Darmstadt, Germany). The crystals were mounted on a goniometer head with epoxy glue. The detector was placed at a distance of $80 \mathrm{~mm}$ from the crystal. A total of 1113 and 4142 frames were collected for $\left(\mathrm{HpipeH}_{2}\right)_{3} \mathrm{I}_{6} \cdot \mathrm{H}_{2} \mathrm{O}$ and $\left(\mathrm{HpipeH}_{2}\right) \mathrm{I}\left(\mathrm{I}_{3}\right)$, respectively. The frames were integrated, and absorption correction was performed with the STOE X-AREA Software package. The structure was solved and refined by full-matrix least-squares procedures on $\left|F^{2}\right|$ using the SHELX97 software [57]. The coordinates of iodide and several Hpipe atoms were found by the direct method. The remaining Hpipe atoms and oxygen atoms (in the case of $\left(\mathrm{HpipeH}_{2}\right)_{3} \mathrm{I}_{6} \cdot \mathrm{H}_{2} \mathrm{O}$ ) were found in the successive difference Fourier syntheses. All atoms were refined anisotropically. After that, all hydrogens near carbon atoms were placed geometrically and refined constrained in the riding mode. For $\left(\mathrm{HpipeH}_{2}\right) \mathrm{I}\left(\mathrm{I}_{3}\right)$, hydrogen atoms bound to nitrogen atoms were located after an alternative series of least-squares cycles and difference Fourier maps and were refined isotropically. For $\left(\mathrm{Hpipe}_{2}\right)_{3} \mathrm{I}_{6} \cdot \mathrm{H}_{2} \mathrm{O}$, two of the hydrogen atoms bound to nitrogen $\mathrm{N} 6$ were found from difference Fourier syntheses. The presence of hydrogen atoms on the N6 atom did not raise any questions: The N-H distances were about $1 \AA$ and the $\mathrm{H} \cdots$ I distances were at $2.65-2.67 \AA$ with the $\mathrm{N}-\mathrm{H} \cdots \mathrm{I}$ angles of $139-147^{\circ}$. Such parameters are common for the $(\mathrm{N}) \mathrm{H} \cdots$ I hydrogen bonds. Some of the remaining ghost peaks could also be attributed to hydrogen atoms associated with nitrogen atoms forming $(\mathrm{N}) \mathrm{H} \cdots$ I hydrogen bonds, but further refinement of the structure was possible only in a rigid body model. Taking into account the requirements of electroneutrality, all remaining hydrogen atoms were placed geometrically and refined constrained in a riding mode. The coordinates of the hydrogen atoms of the water molecules were calculated geometrically, then the $\mathrm{H}-\mathrm{O}$ bond length was fixed as $1 \AA$, the thermal parameter was set as 1.2 times of that of oxygen, and the angles were refined.

A single crystal of $\left(\mathrm{HpipeH}_{2}\right)_{3}\left(\mathrm{H}_{3} \mathrm{O}\right) \mathrm{I}_{7}$ was selected from the synthetic mixture. The single crystal diffraction data were measured at $100 \mathrm{~K}$ on a Bruker D8 VENTURE with PHOTON 100 CMOS detector system equipped with a Mo-target X-ray tube (Bruker, Karlsruhe, Germany). A frame width of $0.50^{\circ}$ and an exposure time of $15 \mathrm{~s} /$ frame were employed for data collection. Data reduction and integration were performed with the Bruker software package SAINT (Version 8.38A, Bruker, 
Karlsruhe, Germany) [58]. Data were corrected for absorption effects using the semi-empirical methods (multi-scan) as implemented in SADABS [59]. The structure was solved by the direct methods using the SHELXTL (Version 2017/1, Institute of Inorganic Chemistry, Göttingen, Germany) program package [60], which gave positions of iodine atoms. Positions of nitrogen and carbon atoms were found from successive difference Fourier syntheses. The hydrogen atoms of the $\mathrm{HpipeH}^{+}$cations were calculated and further refined using riding models. The hydrogen atom positions in $\mathrm{H}_{3} \mathrm{O}^{+}$were found from successive difference Fourier syntheses. Three hydrogen atomic positions were refined freely with their isotropic atomic displacement parameters restricted to 1.5 times their parent oxygen atom equivalent isotropic atomic displacement parameter. Three $\mathrm{H}-\mathrm{O}$ bond distances were restrained to $0.82 \AA$ with an estimated standard deviation of $0.02 \AA$. The crystal structure was refined in anisotropic approximations of atomic displacement parameters for all atoms except hydrogens.

The summary of experimental and crystallographic information for studied compounds is given Table 1. Atomic parameters are listed in Electronic Supporting Information (ESI). Further details of the crystal structures may be obtained from Cambridge Crystallographic Data Centre by quoting the CCDC numbers 1911474, 1911475, 1916483, and 1981548.

\subsection{Thermal Analysis}

Thermogravimetric analysis was performed using a NETZSCH 209 F1 Libra thermobalance (NETZSCH, Selb, Germany). Calibration performed with $\mathrm{CaC}_{2} \mathrm{O}_{4} \cdot 2 \mathrm{H}_{2} \mathrm{O}$ showed that the accuracy of mass detection was better than $0.1 \%$. Samples were heated in alumina crucibles under dry nitrogen flow up to $450{ }^{\circ} \mathrm{C}$ with the heating rate of $5 \mathrm{~K} \cdot \mathrm{min}^{-1}$. The NETZSCH Proteus Thermal Analysis program was used for the data processing.

\subsection{Raman Spectroscopy}

The Raman spectrum of $\left(\mathrm{HpipeH}_{2}\right) \mathrm{I}\left(\mathrm{I}_{3}\right)$ was recorded on a Renishaw In Via spectrometer (Renishaw, Wotton-under-Edge, Great Britain) with laser wavelength of $\lambda=514 \mathrm{~nm}$ (Ar, $50 \mathrm{~mW}$ ). Sample investigation was performed in the backscattering geometry using a confocal microscope Leica DMLM (100' lens) at room temperature in air. Focus distance was $250 \mathrm{~mm}$, and the size of the laser beam was $20 \mu \mathrm{m}$. The CCD-camera (1024 ×368 pixels, Renishaw, Wotton-under-Edge, Great Britain) was used as a detector. The scale calibration was done using monocrystalline silica $\left(521.5 \mathrm{~cm}^{-1}\right) \mathrm{as} \mathrm{a}^{-}$ standard sample. WiRE 3.4 software (Renishaw, Wotton-under-Edge, Great Britain) was used for data processing.

\subsection{Optical Spectroscopy}

Optical diffuse reflectance spectra were recorded using a UV-vis spectrometer Perkin-Elmer Lambda 950 (Perkin-Elmer, Waltham, MA, USA) with an attached diffuse reflectance accessory. Measurements were performed at $298 \mathrm{~K}$ in the spectral range of 250-1200 nm, with a scanning rate of $2 \mathrm{~nm} / \mathrm{s}$ using finely ground polycrystalline samples. The data were processed using the Kubelka-Munk theory approximation and linearized in the $[(k / s) \cdot h v]^{2}-(h v)$ coordinates with $h v$ along the $x$ axis and $[(k / s) \cdot h v]^{2}$ along the $y$ axis, where $k$ is the absorption coefficient, $s$ is the scattering coefficient, and $h$ is the Planck constant [61]. The $(k / s)$ relation known as a remission function was calculated using the refraction data according to the literature as $k / s=(1-R)^{2} / 2 R$, where $R$ is the absolute diffuse reflectance [62]. Extrapolation to $k=0$ gives an approximate value of optical $E_{\mathrm{g}}$ of the material.

\section{Conclusions}

In this work, we have demonstrated the template effect of the $\mathrm{HpipeH}_{2}{ }^{2+}$ cation, which enables assembling different building blocks in polymer crystal structures through strong hydrogen bonds. By utilizing this effect, we were able to synthesize four new compounds, $\left(\mathrm{HpipeH}_{2}\right)_{2} \mathrm{Bi}_{2} \mathrm{I}_{10} \cdot 2 \mathrm{H}_{2} \mathrm{O}$, $\left(\mathrm{HpipeH}_{2}\right)_{3} \mathrm{I}_{6} \cdot \mathrm{H}_{2} \mathrm{O}$, $\left(\mathrm{HpipeH}_{2}\right) \mathrm{I}\left(\mathrm{I}_{3}\right)$, and $\left(\mathrm{HpipeH}_{2}\right)_{3}\left(\mathrm{H}_{3} \mathrm{O}\right) \mathrm{I}_{7}$, of which the former exhibits important 
properties as a potential light-harvesting material. It has considerable thermal stability up to $240{ }^{\circ} \mathrm{C}$ and a low band gap of $1.8 \mathrm{eV}$. We showed that these properties originate from strong hydrogen bonds that tie molecular moieties into the 3D crystal structure.

Supplementary Materials: The following are available online, Figure S1: X-ray powder diffraction pattern for $\left(\mathrm{HpipeH}_{2}\right)_{2} \mathrm{Bi}_{2} \mathrm{I}_{10} \cdot 2 \mathrm{H}_{2} \mathrm{O}$, Figure S2: Thermal analysis data for $\left(\mathrm{H}^{2} \mathrm{pipeH}_{2}\right)_{2} \mathrm{Bi}_{2} \mathrm{I}_{10} \cdot 2 \mathrm{H}_{2} \mathrm{O}$, Figure S3: Thermal analysis data for $\left(\mathrm{HpipeH}_{2}\right)_{3} \mathrm{I}_{6} \cdot \mathrm{H}_{2} \mathrm{O}$, Figure S4: Thermal analysis data for $\left(\mathrm{HpipeH}_{2}\right)_{3} \mathrm{I}_{6} \cdot \mathrm{H}_{2} \mathrm{O}$, Figure S5: Thermal analysis data for $\left(\mathrm{HpipeH}_{2}\right)_{3}\left(\mathrm{H}_{3} \mathrm{O}\right) \mathrm{I}_{7}$ with a slight admixture of $\left(\mathrm{HpipeH}_{2}\right)_{3} \mathrm{I}_{6} \cdot \mathrm{H}_{2} \mathrm{O}$ Table S1: Atomic parameters in the crystal structure of $\left(\mathrm{HpipeH}_{2}\right)_{2} \mathrm{Bi}_{2} \mathrm{I}_{10} \cdot 2 \mathrm{H}_{2} \mathrm{O}$, Table S2: Atomic parameters in the crystal structure of $\left(\mathrm{HpipeH}_{2}\right) \mathrm{I}\left(\mathrm{I}_{3}\right)$, Table S3: Atomic parameters in the crystal structure of $\left(\left(\mathrm{HpipeH}_{2}\right)_{3} \mathrm{I}_{6} \cdot \mathrm{H}_{2} \mathrm{O}\right.$, Table S4: Atomic parameters in the crystal structure of $\left(\mathrm{HpipeH}_{2}\right)_{3}\left(\mathrm{H}_{3} \mathrm{O}\right) \mathrm{I}_{7}$.

Author Contributions: Conceptualization, T.A.S.; methodology, A.V.M.; investigation, T.A.S., M.A.B., Z.W. and A.V.G.; writing-original draft preparation, T.A.S. and A.V.S.; writing-review and editing, E.V.D. and A.V.S.; Supervision, E.V.D. and A.V.S. All authors have read and agreed to the published version of the manuscript.

Funding: This research was supported by the Russian Science Foundation, grant No. 19-73-30022.

Acknowledgments: We thank N. A. Yelavik for her help with the synthetic work on early stages and Dr. V. A. Tafeenko for his assistance with X-ray diffraction experiments.

Conflicts of Interest: The authors declare no conflict of interest.

\section{References}

1. Ruck, M. In My Element: Bismuth. Chem. Eur. J. 2019, 25, 13-14. [CrossRef]

2. Lichtenberger, N.; Massa, W.; Dehnen, S. Polybismuthide Anions as Ligands: The Homoleptic Complex $\left[\left(\mathrm{Bi}_{7}\right) \mathrm{Cd}\left(\mathrm{Bi}_{7}\right)\right]^{4-}$ and the Ternary Cluster $\left[\left(\mathrm{Bi}_{6}\right) \mathrm{Zn}_{3}\left(\mathrm{TlBi}_{5}\right)\right]^{4-}$. Angew. Chem. Int. Ed. 2019, 58, 3222-3226. [CrossRef] [PubMed]

3. Weiz, A.; Lê Anh, M.; Kaiser, M.; Rasche, B.; Herrmannsdorfer, T.; Doert, T.; Ruck, M. Optimized Synthesis of the Bismuth Subiodides $\mathrm{Bi}_{\mathrm{m}} \mathrm{I}_{4}(\mathrm{~m}=4,14,16,18)$ and the Electronic Properties of $\mathrm{Bi}_{14} \mathrm{I}_{4}$ and $\mathrm{Bi}_{18} \mathrm{I}_{4}$. Eur. J. Inorg. Chem. 2017, 47, 5609-5615. [CrossRef]

4. Groh, M.F.; Isaeva, A.; Frey, C.; Ruck, M. $\left[\mathrm{Ru}\left(\mathrm{Bi}_{8}\right)_{2}\right]^{6+}-\mathrm{A}$ Cluster in a Highly Disordered Crystal Structure is the Key to the Understanding of the Coordination Chemistry of Bismuth Polycations. Z. Anorg. Allg. Chem. 2013, 639, 2401-2405. [CrossRef]

5. Baranov, A.I.; Kloo, L.; Olenev, A.V.; Popovkin, B.A.; Romanenko, A.I.; Shevelkov, A.V. Unique Metallic Wires ${ }_{\infty}^{1} \mathrm{Ni}_{8} \mathrm{Bi}_{8} \mathrm{~S}$ in a Novel Quasi-1D Compound. Synthesis, Crystal and Electronic Structure, and Properties of $\mathrm{Ni}_{8} \mathrm{Bi}_{8}$ SI. J. Am. Chem. Soc. 2001, 123, 12375-12379. [CrossRef]

6. Dikarev, E.V.; Popovkin, B.A.; Shevelkov, A.V. The crystal structure of $\mathrm{Bi}_{14} \mathrm{I}_{4}$ condensed bismuth clusters. Z. Anorg. Allg. Chem. 1992, 612, 118-122. [CrossRef]

7. Von Schnering, H.-G.; Benda, H.V.; Kalveram, C. Wismutmonojodid BiJ, eine Verbindung mit Bi(O) und Bi(II). Z. Anorg. Allg. Chem. 1978, 438, 37-52. [CrossRef]

8. Friedman, R.M.; Corbett, J.D. Bismuth(I) in the solid state. The crystal structure of $\left(\mathrm{Bi}^{+}\right)\left(\mathrm{Bi}_{9}{ }^{5+}\right)\left(\mathrm{HfCl}_{6}{ }^{2-}\right)_{3}$. J. Chem. Soc. D Chem. Commun. 1971, 9, 422-423. [CrossRef]

9. Shi, Z.; Guo, J.; Chen, Y.; Li, Q.; Pan, Y.; Zhang, H.; Xia, Y.; Huang, W. Lead-Free Organic-Inorganic Hybrid Perovskites for Photovoltaic Applications: Recent Advances and Perspectives. Adv. Mater. 2017, 29, 1605005. [CrossRef]

10. Ganose, A.M.; Savory, C.N.; Scanlon, D.O. Beyond methylammonium lead iodide: Prospects for the emergent field of $n \mathrm{~s}^{2}$ containing solar absorbers. Chem. Commun. 2017, 53, 20-44. [CrossRef]

11. Stroyuk, O. Lead-free hybrid perovskites for photovoltaics. Beilstein J. Nanotechnol. 2018, 9, $2209-2235$. [CrossRef] [PubMed]

12. Shin, J.; Kim, M.; Jung, S.; Kim, C.S.; Park, J.; Song, A.; Chung, K.-B.; Jin, S.-H.; Lee, J.H.; Song, M. Enhanced efficiency in lead-free bismuth iodide with post treatment based on a hole-conductor-free perovskite solar cell. Nano Res. 2018, 11, 6283-6293. [CrossRef]

13. Hu, Y.-Q.; Hui, H.-Y.; Lin, W.-Q.; Wen, H.-Q.; Yang, D.-S.; Feng, G.-D. Crystal and Band-Gap Engineering of One-Dimensional Antimony/Bismuth-Based Organic-Inorganic Hybrids. Inorg. Chem. 2019, 58, 16346-16353. [CrossRef] [PubMed] 
14. Anyfantis, G.C.; Ioannou, A.; Barkaoui, H.; Abid, Y.; Psycharis, V.; Raptopoulou, C.P.; Mousdis, G.A. Hybrid halobismuthates as prospective light-harvesting materials: Synthesis, crystal, optical properties and electronic structure. Polyhedron 2020, 175, 114180. [CrossRef]

15. Zhang, L.; Wang, K.; Zou, B. Bismuth Halide Perovskite-Like Materials: Current Opportunities and Challenges. ChemSusChem 2019, 12, 1612-1630. [CrossRef] [PubMed]

16. Mercier, N.; Louvain, N.; Bi, W. Structural diversity and retro-crystal engineering analysis of iodometalate hybrids. CrystEngComm 2009, 11, 720-734. [CrossRef]

17. Adonin, S.A.; Sokolov, M.N.; Fedin, V.P. Polynuclear halide complexes of Bi(III): From structural diversity to new properties. Coord. Chem. Rev. 2016, 312, 1-21. [CrossRef]

18. Erbe, M.; Kohler, D.; Ruck, M. A Water Sensitive Hydrate: The Bis-Catena Complex Salt $\left[\mathrm{Mn}\left(\mathrm{H}_{2} \mathrm{O}\right)_{6}\right]\left[\mathrm{BiI}_{4}\right]_{2} \cdot 2 \mathrm{H}_{2} \mathrm{O}$. Z. Anorg. Allg. Chem. 2010, 636, 1513-1515. [CrossRef]

19. Yelovik, N.A.; Mironov, A.V.; Bykov, M.A.; Kuznetsov, A.N.; Grigorieva, A.V.; Wei, Z.; Dikarev, E.V.; Shevelkov, A.V. Iodobismuthates Containing One-Dimensional $\mathrm{BiI}_{4}{ }^{-}$Anions as Prospective Light-Harvesting Materials: Synthesis, Crystal and Electronic Structure, and Optical Properties. Inorg. Chem. 2016, 55, 4132-4140. [CrossRef]

20. Yelovik, N.A.; Shestimerova, T.A.; Bykov, M.A.; Wei, Z.; Dikarev, E.V.; Shevelkov, A.V. Synthesis, structure, and properties of $\mathrm{LnBiI}_{6} \cdot 13 \mathrm{H}_{2} \mathrm{O}(\mathrm{Ln}=\mathrm{La}, \mathrm{Nd})$. Russ. Chem. Bull. Int. Ed. 2017, 66, 1196-1201. [CrossRef]

21. Zhu, H.; Pan, M.; Johansson, M.B.; Johansson, E.M.J. High Photon-to-Current Conversion in Solar Cells Based on Light-Absorbing Silver Bismuth Iodide. ChemSusChem 2017, 10, 2592-2596. [CrossRef] [PubMed]

22. Jain, S.M.; Phuyal, D.; Davies, M.L.; Li, M.; Philipp, B.; De Castro, C.; Qiu, Z.; Kim, J.; Watson, T.; Tsoi, W.C.; et al. An effective approach of vapour assisted morphological tailoring for reducing metal defect sites in lead-free, $\left(\mathrm{CH}_{3} \mathrm{NH}_{3}\right)_{3} \mathrm{Bi}_{2} \mathrm{I}_{9}$ bismuth-based perovskite solar cells for improved performance and long-term stability. Nano Energy 2018, 49, 614-624. [CrossRef]

23. Shao, Z.; Le Mercier, T.; Madec, M.B.; Pauporté, T. AgBi ${ }_{2} \mathrm{I}_{7}$ layers with controlled surface morphology for solar cells with improved charge collection. Mater. Lett. 2018, 221, 135-138. [CrossRef]

24. Mashadieva, L.F.; Aliev, Z.S.; Shevelkov, A.V.; Babanly, M.B. Experimental investigation of the Ag-Bi-I ternary system and thermodynamic properties of the ternary phases. J. Alloys Compd. 2013, 551, 512-520. [CrossRef]

25. Zhang, Z.; Li, X.; Xia, X.; Wang, Z.; Huang, Z.; Lei, B.; Gao, Y. High-Quality $\left(\mathrm{CH}_{3} \mathrm{NH}_{3}\right)_{3} \mathrm{Bi}_{2} \mathrm{I}_{9}$ Film-Based Solar Cells: Pushing Efficiency up to 1.64\%. J. Phys. Chem. Lett. 2017, 8, 4300-4307. [CrossRef] [PubMed]

26. Pazoki, M.; Edvinsson, T. Metal replacement in perovskite solar cell materials: Chemical bonding effects and optoelectronic properties. Sustain. Energy Fuels 2018, 2, 1430-1445. [CrossRef]

27. Sansom, H.C.; Whitehead, G.F.S.; Dyer, M.S.; Zanella, M.; Manning, T.D.; Pitcher, M.J.; Whittles, T.J.; Dhanak, V.R.; Alaria, J.; Claridge, J.B.; et al. $\mathrm{AgBiI}_{4}$ as a Lead-Free Solar Absorber with Potential Application in Photovoltaics. Chem. Mater. 2017, 29, 1538-1549. [CrossRef]

28. Shestimerova, T.A.; Yelavik, N.A.; Mironov, A.V.; Kuznetsov, A.N.; Bykov, M.A.; Grigorieva, A.V.; Shevelkov, A.V. From Isolated Anions to Polymer Structures through Linking with $\mathrm{I}_{2}$ : Synthesis, Structure, and Properties of Two Complex Bismuth(III) Iodine Iodides. Inorg. Chem. 2018, 57, 4077-4087. [CrossRef]

29. Lehner, A.J.; Fabini, D.H.; Evans, H.A.; Hébert, C.-A.; Smock, S.R.; Hu, J.; Wang, H.; Zwanziger, J.W.; Chabinyc, M.L.; Seshadri, R. Crystal and Electronic Structures of Complex Bismuth Iodides $A_{3} \mathrm{Bi}_{2} \mathrm{I}_{9}(A=\mathrm{K}$, $\mathrm{Rb}, \mathrm{Cs}$ ) Related to Perovskite: Aiding the Rational Design of Photovoltaics. Chem. Mater. 2015, 27, 7137-7148. [CrossRef]

30. Zhang, W.; Liu, X.; Li, L.; Sun, Z.; Han, S.; Wu, Z.; Luo, J. Triiodide-induced band-edge reconstruction of a lead-free perovskite-derivative hybrid for strong light absorption. Chem. Mater. 2018, 30, 4081-4088. [CrossRef]

31. Zhang, W.; Kou, B.; Peng, Y.; Wu, Z.; Yao, Y.; Dey, D.; Lia, L.; Luo, J. Rational design of a triiodide-intercalated dielectric-switching hybrid for visible-light absorption. J. Mater. Chem. C 2018, 6, 12170-12174. [CrossRef]

32. Kotov, V.Y.; Ilyukhin, A.B.; Sadovnikov, A.A.; Birin, K.P.; Simonenko, N.P.; Nguyen, H.T.; Baranchikov, A.E.; Kozyukhin, S.A. Bis (4-cyano-1-pyridino) pentane halobismuthates. Light-harvesting material with an optical band gap of $1.59 \mathrm{eV}$. Mendeleev Commun. 2017, 27, 271-273. [CrossRef]

33. Kotov, V.Y.; Ilyukhin, A.B.; Korlyukov, A.A.; Smol'yakov, A.F.; Kozyukhin, S.A. Black hybrid iodobismuthate containing linear anionic chains. New J. Chem. 2018, 42, 6354-6363. [CrossRef] 
34. Li, T.; Wang, Q.; Nichol, G.S.; Morrison, C.A.; Han, H.; Hu, Y.; Robertson, N. Extending lead-free hybrid photovoltaic materials to new structures: Thiazolium, aminothiazolium and imidazolium iodobismuthates. Dalton Trans. 2018, 47, 7050-7058. [CrossRef]

35. Zhang, X.; Zhang, P.; Weng, Y.-G.; Tang, Z.-Z.; Zhu, Q.-Y.; Dai, J. Intracation and interanion-cation charge-transfer properties of tetrathiafulvalene-bismuth-halide hybrids. Inorg. Chem. 2018, 57, 11113-11122. [CrossRef]

36. Dehnhardt, N.; Luy, J.-N.; Szabo, M.; Wende, M.; Tonner, R.; Heine, J. Synthesis of a two-dimensional organic-inorganic bismuth iodide metalate through in situ formation of iminium cations. Chem. Commun. 2019, 55, 14725-14728. [CrossRef] [PubMed]

37. Shestimerova, T.A.; Mironov, A.V.; Bykov, M.A.; Starichenkova, E.D.; Kuznetsov, A.N.; Grigorieva, A.V.; Shevelkov, A.V. Reversal Topotactic Removal of Acetone from $(\mathrm{HMTH})_{2} \mathrm{BiI}_{5} \cdot\left(\mathrm{CH}_{3}\right)_{2} \mathrm{C}=\mathrm{O}$. Accompanied by Rearrangement of Weak Bonds, from 1D to 3D Patterns. Cryst. Growth Design 2020, 20, 87-94. [CrossRef]

38. Shestimerova, T.A.; Golubev, N.A.; Yelavik, N.A.; Bykov, M.A.; Grigorieva, A.V.; Wei, Z.; Dikarev, E.V.; Shevelkov, A.V. Role of $\mathrm{I}_{2}$ Molecules and Weak Interactions in Supramolecular Assembling of Pseudo-Three-Dimensional Hybrid Bismuth Polyiodides: Synthesis, Structure, and Optical Properties of Phenylenediammonium Polyiodobismuthate(III). Cryst. Growth Design 2018, 18, 2572-2578. [CrossRef]

39. Li, T.; Hu, Y.; Morrison, C.A.; Wu, W.; Hana, H.; Robertson, N. Lead-free pseudo-three-dimensional organic-inorganic iodobismuthates for photovoltaic applications. Sustain. Energy Fuels 2017, 1, 308-316. [CrossRef]

40. Liebing, P.; Stein, F.; Hilfert, L.; Lorenz, V.; Oliynyk, K.; Edelmann, F.T. Synthesis and structural investigation of brightly colored organoammonium violurates. Z. Anorg. Allg. Chem. 2019, 645, 36-43. [CrossRef]

41. Dennington, A.J.; Weller, M.T. Synthesis and structure of pseudo-three-dimensional hybrid iodobismuthate semiconductors. Dalton Trans. 2016, 45, 17974-17979. [CrossRef] [PubMed]

42. Adonin, S.A.; Gorokh, I.D.; Novikov, A.S.; Samsonenko, D.G.; Yushina, I.V.; Sokolov, M.N.; Fedin, V.P. Halobismuthates with halopyridinium cations: Appearance or non-appearance of unusual colouring. CrystEngComm 2018, 20, 7766-7772. [CrossRef]

43. Nesterova, O.V.; Petrusenko, S.R.; Dyakonenko, V.V.; Shishkin, O.V.; Linert, W. A three-dimensional framework of bis [tris(ethylenediamine)zinc] tetraiodocadmate diiodide assisted by $\mathrm{N}-\mathrm{H} \cdots \mathrm{I}$ hydrogen bonds. Acta Crystallogr. C 2006, 62, 281-283. [CrossRef] [PubMed]

44. Trigui, A.; Boughzala, H.; Driss, A.; Abid, Y. The one-dimensional organic inorganic hybrid: catena-poly[bis[1-(3-ammoniopropyl)-1 $H$-imidazolium] [[iodidoplumbate(II)]-tri- $\mu$-iodido-plumbate(II)-tri- $\mu$ iodido-[iodidoplumbate(II)]-di- $\mu$-iodido]]. Acta Crystallogr. E 2011, 67, 458-459. [CrossRef] [PubMed]

45. Alvarez, S. A cartography of the van der Waals territories. Dalton Trans. 2013, 42, 8617-8636. [CrossRef] [PubMed]

46. Chang, J.-H.; Albrecht, R.; Doert, T.; Ruck, M. The Water-Rich Iodidobismuthate $\left(\mathrm{H}_{3} \mathrm{O}\right) \mathrm{Rb}_{3} \mathrm{BiI}_{7} \cdot 4 \mathrm{H}_{2} \mathrm{O}$. Z. Anorg. Allg. Chem. 2019, 645, 1-6.

47. Svensson, P.H.; Kloo, L. Synthesis, Structure, and Bonding in Polyiodide and Metal Iodide-Iodine Systems. Chem. Rev. 2003, 103, 1649-1684. [CrossRef]

48. Savinkina, E.V.; Mavrin, B.N.; Albov, D.V.; Kravchenko, V.V.; Zaitseva, M.G. Polyiodide amide complexes of transition metals: Structures and Raman spectra. Russ. J. Coord. Chem. 2009, 35, 96. [CrossRef]

49. Shestimerova, T.A.; Bykov, M.A.; Wei, Z.; Dikarev, E.V.; Shevelkov, A.V. Crystal structure and two-level supramolecular organization of glycinium triiodide. Russ. Chem. Bull. Int. Ed. 2019, 68, 520-1524. [CrossRef]

50. Yushina, I.; Tarasova, N.; Kim, D.; Sharutin, V.; Bartashevich, E. Noncovalent Bonds, Spectral and Thermal Properties of Substituted Thiazolo[2,3-b][1,3]thiazinium Triiodides. Crystals 2019, 9, 506. [CrossRef]

51. Oswald, W.H.; Mozur, E.M.; Moseley, I.P.; Ahn, H.; Neilson, J.R. Hybrid Charge-Transfer Semiconductors: $\left(\mathrm{C}_{7} \mathrm{H}_{7}\right) \mathrm{SbI}_{4},\left(\mathrm{C}_{7} \mathrm{H}_{7}\right) \mathrm{BiI}_{4}$, and Their Halide Congeners. Inorg. Chem. 2019, 58, 5818-5826. [CrossRef] [PubMed]

52. Zhang, Z.-P.; Feng, Q.-Y.; Wei, Y.-L.; Gao, Z.-Y.; Wang, Z.-W.; Wang, Y.-M. Three Iodobismuthates Hybrids Displaying Mono-nuclear, Dimer and 1-D Arrangements Templated by 1,4-diazabicyclo[2.2.2]octane Derivatives: Semiconductor and Photocurrent Response Properties. J. Clust. Sci. 2018, 29, 725-735. [CrossRef]

53. Chen, B.-G. Organic/Bismuth Iodides Hybrids: Structural Perturbation of Substitutes and Their Photocurrent Response Properties. J. Clust. Sci. 2017, 28, 983-994. [CrossRef] 
54. Hoefler, S.F.; Rath, T.; Fischer, R.; Latal, C.; Hippler, D.; Koliogiorgos, A.; Galanakis, I.; Bruno, A.; Fian, A.; Dimopoulos, T.; et al. A zero-dimensional mixed-anion hybrid halogenobismuthate (III) semiconductor: Structural, optical, and photovoltaic properties. Inorg. Chem. 2018, 57, 10576-10586. [CrossRef]

55. Burla, M.C.; Camalli, M.; Carrozzini, B.; Cascarano, G.; Giacovazzo, C.; Polidori, G.; Spagna, R. SIR2002: The program. J. Appl. Cryst. 2003, 36, 1103. [CrossRef]

56. Petricek, V.; Dusek, M.; Palatinus, L. Jana2000. In Structure Determination Software Programs; Institute of Physics: Prague, Czech Republic, 2000.

57. Sheldrick, G.M. SHELX97. In Program for the Solution and Refinement of Crystal Structures; University of Gottingen: Gottingen, Germany, 1997.

58. SAINT, Version 8.38A; Bruker AXS Inc.: Madison, WI, USA, 2019.

59. Krause, L.; Herbst-Irmer, R.; Sheldrick, G.M.; Stalke, D. Comparison of silver and molybdenum microfocus X-ray sources for single-crystal structure determination. J. Appl. Cryst. 2015, 48, 3-10. [CrossRef]

60. Sheldrick, G.M. SHELXT-Integrated space-group and crystal-structure determination. Acta Cryst. 2015, C71, 3-8. [CrossRef]

61. Kubelka, P.; Munk, F. Ein Beitrag zur Optik der Farbanstriche (Contribution to the optic of paint). Z. Tech. Phys. (Leipzig) 1931, 12, 593-601.

62. Fedeli, P.; Gazza, F.; Calestani, D.; Ferro, P.; Besagni, T.; Zappettini, A.; Calestani, G.; Marchi, E.; Ceroni, P.; Mosca, R. Influence of the synthetic procedures on the structural and optical properties of mixed-halide (Br, I) perovskite films. J. Phys. Chem. C 2015, 119, 21304-21313. [CrossRef]

Sample Availability: Samples of the compounds are not available.

(C) 2020 by the authors. Licensee MDPI, Basel, Switzerland. This article is an open access article distributed under the terms and conditions of the Creative Commons Attribution (CC BY) license (http://creativecommons.org/licenses/by/4.0/). 